\section{Queries and Minor Notes.}

Asonmoles Compenications will not be noticed. Queries for this colum must be accompanied by the writer's name and address. but the reguest of the writer not to publish his name will be faith. fully observed.

\section{REQIIREMLATS FOR MEDICAL PRACTICE.}

\section{Í́NOXVille, Tenn., Sept. 20, 1902.}

I'o the Eflifor:-Will you kindly give me through these columns the legal refuirements for practicing medicine in Arizona, Colorado, Mexico and liritish Columbia?

J. P. W.

Axs.- In Arizona an examination and satisfactory diploma are reguired. In Colorado a diploma approved by the State Board of Medical Fxaminers. In Mexico a rigid examination in the Spanish language and elaborate identitications of the individual and his medical credentials. In Iritish Columbia an approved diploma, identilication and a satisfactory examination.

\section{SEI'TRESSION OF URINIE}

I'AIIS, IIL., Oct. 20, 1902.

- To the tillitor: In the fall of 1880 Mrs. S. had complete suppression of urine. After trying diuretics for more than a week, we prescribed a glass of water every two hours, and in less than twenty-foul hour's her kidneys began to act. In case the stomach would not retain water, I would give a salt solution either by enema or hypodermically. Is it not possible that in Dr. Seiler's case (Tнғ Jolixal, October 11, p. 915) the sweating, vomiting and purging hat something to do with the suppression? W. H. Ten Broeck.

\section{Gorrespondence.}

\section{Organization.}

WICKLIFFE, OHIO, Oct. 13, 1902.

Your article on the chatic condition of the medical profession as regards its power and influence with the public because - its lack of organization and unity is very timely and to the point. It is to be regretted that the medical profession with all its boasted learning and conceit does not command any power political or civil, compared to organized labor to-day. The profession is not so numerous but that if it were so thoroughly organized as labor, and its individual members more governel by the single-mindedness and good sense of which it boasts, it could wield a tremendous power in politics and sould command any reasonable compensation it demanded for services rendered to the state, corporations or individuals. Members of the profession of theology and law far outstrip us today in the respect and power they command in state and civil affairs.

If this were not so we would not have the hordes of competent physicians all over the country that we have to-day struggling with poverty and coming to old age without a competence, hardly able to eain enough to live decently and educate two or three children as they ought.

I will cite the condition of the profession in Ohio to-day, which could be remedied by organization. The coroner of Lake County treats 350 lodge nembers for $\$ 1$ a year each. He has a contract to treat the poor of a population of 2,500 people, three-fourths laboring people, for $\$ 25$ per year-worth $\$ 300$ to $\$ 500$, also a contract with the county directors of infirmary to go a distance of nearly five miles and treat the inmates for $\$ 100$ a year. Township trustees, in nearly every township in the state, farm out the poor for treatment in many instances to incompetent or unscrupulous physicians, for about $\$ 50$ a year for work that if fair fees were paid would amount to anywhere from $\$ 200$ to $\$ 500$ a year.

The Lake Shore Railroad Company does not pay any of its local railroad surgeons, a pass being the only remuneration. At Ashtabula, Ohio, there is more than $\$ 1,000$ worth of work in the yards every year. At Collinwood, where the yards of the L. S. \& M. S. R. R. - the greatest shops in the world-are located, employing nearly 3,000 men, two young surgeons are paid the magnificent salary of $\$ 100$ a year for tending to the accident work of all employes. The P. \& W., now a branch of the B. \& O., at Painesville, Ohio, where their terminal employs a large number of men, pay the surgeon $\$ 100$ a year, I am told by a doctor who once held the appointment.
The writer has been doing the accidental surgery for a small steel structural plant, recently moved to this place from Cleveland. Recently I charged $\$ 1.50$ for removing a speck of steel from the eye of an employe. I had also dressed a scalp wound for another employe which took more than an hour, and in which it was necessary to insert five stitches; the patient was suffering from slight concussion and the wound and hair was filled with clot and shop dirt. My bill for this was $\$ 5$.

The company informed me that it had not paid more than $\$ 1$ for removing bodies from the eye, nor more than $\$ 3$ for dressing any scalp wound, in Cleveland. That they would pay such and such fees for such and such injuries, and hoped that I would see very clear to render services to employes at terms stipulated by them, and that if I would reduce the above rendered bill to $\$ 1$ and $\$ 3$ respectively, they would mail check.

The members of the profession are constantly humiliated and insulted by wealthy corporations, state, county and city officials. Why? Because, as a lawyer once said in an import ant case, "doctors are all a set of $d-$ fools," and because the profession is not organized. If the physicians of this county and Cuyahoga were organized as they should be with a uniform fee bill, having a black list and protection features, I could reply to the officers of that plant that the profession of the county had a fee bill, the terms of which I could not deviate from, and that if they did not want to pay my charges for services rendered I did not have to do the work. As it is, if I do not accept the fees the company offers, the work will go to another physician and the company knows it can get plenty of doctors to do their work for whatever they are willing to pay. What the medical profession needs is a leader, to take it out of the valley of poverty and humiliation, a Mitchell, as the miners have, or a Morgan, as the trusts have.

F. H. Topd, M.D.

\section{Unfair Tests.}

San Francisco, Oct. 11, 1902.

To the Editor:-In your editorial on "Unfair Tests," in the issue of October 4, you discuss the criticism by the Pacific Medical Journal of the questions in pathology submitted by the California State Board of Medical Examiners. In order that your deductions should have full value, it seems to me fair that a full knowledge of the truth of the facts in your premises should be given you. You suppose that the writer of the editorial in the Pacific Medical Journal is correct in stating that some were rejected for failure to answer the questions to which exception was taken-"Define cryoscopy," and "What are the characteristic lesions of Hanot's cirrhosis." First, as to the truth of this. The editor of the Pacifio Medical Journal is dean of a recently organized medical school in San Francisco and president and manager of its board of trustees. Out of a class of 40 or more graduates from this school, 11 chosen ones took the examination; certain of the others have openly stated that they never intended to take any state examination, and our worthy governor has recently given one of these a medicopolitical job. Of the 11 who took the examination, 6 failed in 4 or 5 of the 9 subjects. From the other two regular schools of San Francisco represented at the examination, there were 48 candidates, and 3 failed. Only one candidate was conditioned in pathology, having obtained less than the required 60 per cent.

Secondly, over 75 per cent. of the candidates defined Hanot's cirrhosis more accurately than you have done in your editorial. This places the statement of the editor of the Pacific Medical Journal where it belongs. As you say yourself "from the published questions, the examinations seem eminently fair in all other respects," I think it only just to your readers to state that the examinations were particularly easy and were easily marked. A few questions may have been asked rather to test the kind of teaching done in some of the schools than to catch the students; but when a school, in this age, graduates a man who defines intussusception as "the susceptibility of some people to disease," it is time that the respectable element of the profession take steps to protect itself as well as the public by ascertaining the quality of the teaching in our institutions 
and by ferreting out those who display both ignorance and defiance of the law. Respectfully your's,

Dudley TaIt, Vice-Pres. Cal State Bd. Med. Exam.

\section{Incompetent Hospital Management.}

Chicago, Oct. 15, 1902.

T'c the Editor:- My attention has been called to an article in your number of October 11 [pages 918 and 920] speaking of one of our nurses who was concerned in the late accident at the Presbyterian Hospital and stating that the nurse had been dismissed. This is not correct. She has not been dismissed, nor have we the slightest intention of dismissing her. She went home because sle was very much disturbed and unstrung, as was perfectly natural, though the chief blame did not rest on her, but on the person who sent $1 \mathrm{gr}$. strychnin tablets to the ward, where the only ones usual and permitted are $1 / 60$ grain. The fault of the nurse was only in the fact that she assumed that the tablets were the usual ones, and did not read the full label to see. Her career is not ended; she will finish her course, and no one who knows the full facts can feel anything but sympathy for her, in that she has suffered acutely, while not seriousiy in fault.

LUCY L. Flower

17\% Lake View Arenue. President Illinois Training School for Nurses.

\section{State Boards of Registration.}

Montana Report.-Dr. William C. Riddell, secretary of the Board of Medical Examiners of Montana, reports the examination held at Helena, October 7, 8 and 9, as follows: Number of subjects, 14 ; questions, 70 ; percentage required to pass, 75 ; written examination; total number examined, 20 ; passed, 16 ; tailed, 4.

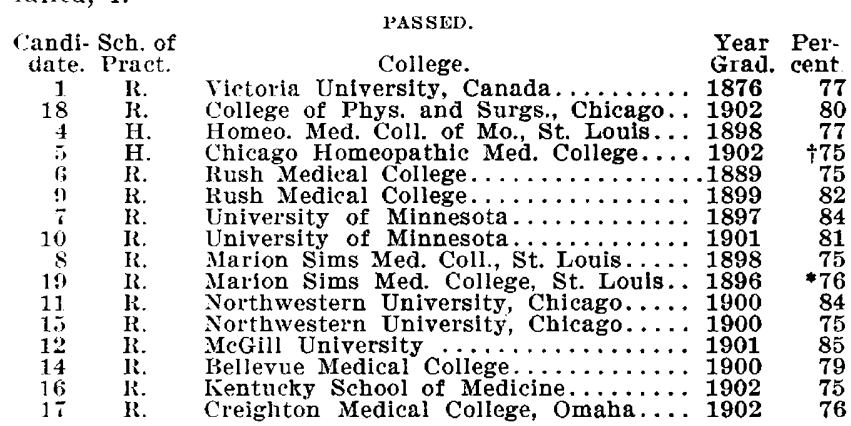
FAILED.

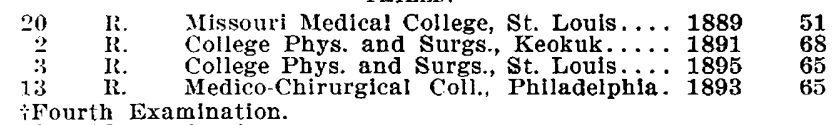
* Second examination.

Thirty States Will Reciprocate-President J. R. Currens, of the Wisconsin Board of Medical Examiners, announces for the Federation of Reciprocal Examining Boards that probably thirty states will unite in the arrangements. The next meeting is to be held in Chicago in November.

Ohio Board Revokes Licenses.--The Ohio State Board of Medical Registration and Examination revoked the licenses of Drs. A. E. Hoskinson and Charles F. Cookes of Columbus, October 7 , for alleged criminal malpractice. It is stated that the state's attorney will follow this with prosecution in the rriminal courts.

Western States to Reciprocate.-Following a call from the Kansas and Missouri boards, representatives from Iowa and Nebraska met with them October 15 at Kansas City and discussed reciprocal recognition of certificates. A further meeting will be held, November 17 , at Kansas City. Illinois, Texas, Colorado, Arkansas, Oklahoma and New Mexico are also asked to join in the arrangements.

Photographs to be Shown in Missouri.-The State Board of Health has decided to require photographic identification of candidates, because of several attempts at impersonation of other persons they allege to have occurred. The board was in session October 15 and 16 . It is stated that the license to practice of Dr. Lyman B. Powell was revoked on the alleged ground of habitual drunkenness. Other cases of unprofessional conduct were before the board, but not acted on.

Utah to Reciprocate.-At the quarterly meeting, October 7 , of the Utah Board of Medical Examiners, a resolution was passed instructing the secretary to communicate with medical boards of other states with a riew to a reciprocal acceptance of certificates of efficiency to practice medicine and surgery. An other resolution was passed to notify all such as use the title of doctor without warrant that they will be prosecuted there fore under the state statute covering this offense.

\section{Misgellany.}

\section{The Indiana Practice Law.}

The Supreme Court of Indiana has just given out a decision that seems to settle the status of the practice law of that state as regards a large class of irregular practitioners. One Parks, a "magnetic healer," was convicted in the Lawrence" County Circuit Court of violating the medical law. He advertised himself as professor and magnetic healer, was not a graduate of any school of medicine and had no license. His treat ment, so far as there was anything manual about it, consisted in holding the affected parts and rubbing. The court's decision affirms the validity of the indictment and of the statute which had been challenged by the appellant, the latter as a proper application of the police powers of the state. It says:

lt appears from the evidence that at the time in question the appeliant practiced magnetic healing. and had done so for eigh years prior thereto ; that he did not use medicines or surgery; that styled himself "profor". an styled himself "professor"; that he was not a graduate of any school of medicine and had no license; that he diagnosed case entirely by the nerves; that on April 8, 1901, one Edward Garve came to him, to be treated for a lame ankle; that after examining the ankle appellant diagnosed the case as rheumatism, and pro as there was anything manual about it, in holding the affected parts and rubbing them. An effort on the part of the appeliant, while testifying as a witness, to describe magnetic healing was prefaced by the statement that "It is pretty hard to describe for people to understand." At this point he was interrupted by the court, and the subject does not seem to have been pursued further. Appellant charged and received one dollar for the treatment that he gave said act under which he was convicted is valid.

For hundreds of years the matter of the conservation of the pub lic health has been a leading matter of police control If pub holds himself out to the community as a person skilled in the science of healing and on that ground seeks the opportunity in the cise the skill he claims to possess, his business becomes impressed with a public character, and be is therefore subject to reasonable regulation in its prosecution.

The limitations of the police power by the Federal Constitution, especially as regards discrimination against personal rights, are discussed by the court, which says:

Counsel for appellant denounce the law in question as "an attempt to determine a question of science and control the personal conduct of the citizen without regard to his opinion, and in a mat ter in which the public is in no wise concerned." We think, on the contrary, that the matter is one of very considerable concern, and that the legislature is the appropriate tribunal to determine the degree of learning that those who gain a livelihood by seeking to
relieve the bodily ailments of others should possess. While it is relieve the bodily ailments of others should possess. While it is true that the of ten-quoted definition of police power afforded by tains the limitation that such laws must be wholesome and reason able, yet it is evident, as the power to enact laws has been confided to the legislative department, that a ver'y large measure of authority is vested in that department to determine what is reasonable and wholesome in the enactment of statutes under the police power The courts would never venture to run a race of opinion with the
legislature on questions of mere expediency. Such a course would legislature on questions of mere expedie

The title of the medical practice act was claimed to be insufficient as not in accordance with the constitutional provision that every act shall embrace but one subject and matters properly connected therewith, which subject shall be expressed in the title. This claim is disposed of by the court, which says:

We do not think that there is involved in this case a question as to the authority of the legislature to discriminate against a partic ular school of practitioner's. We are not judicially advised that magnetic healing, so-called, is so far based on coördinated, arranged and cystematized knowledge that it can be termed a science, or tha any considerable degree of instruction is a prerequisite to its pros ecution as it is actually practiced by those whose knowledge does not go beyond the manifestation of the phenomena of magnetism It may have been the judgment of the legislature in its implied exclusion of appellant, that both the limitations of value that the treatment possessed and the dangers attending it made it wise to confine its use to a body of men in whose hands it would be safer administration. 